\title{
Chemical and enzymatic transformations of progesterone in simulation water treatment processes at laboratory scale
}

The removal of endocrine disrupting compounds (EDCS) present in waters and effluents has been proposed both by physical, chemical, and biological treatment methods and by the use of enzymes produced by living beings. While some methods prove efficient, it is known that steroid transformation can generate byproducts with similar or increased disruptive capacity over the parent compounds. This study aimed to evaluate the removal of the progesterone molecule in oxidizing and enzymatic media and. to verify the formation of by-products. The samples were evaluated under different conditions when submitted to oxidizing media ( $\mathrm{pH}$, time, temperature, salinity) and enzyme medium ( $\mathrm{pH}$, time, enzymatic concentration). From the analyses, it was verified that the samples submitted to the oxidizing media presented lower average removal (18.7\%) than the samples submitted to enzyme laccase (36.7\%). Among the samples submitted to the oxidizing media, the positive influence of hydrogen peroxide on the average removal of progesterone (20.8\%) was observed. While for the samples submitted to the enzymatic medium progesterone removal favored (43.9\%) occurred in buffer solution $\mathrm{pH} 5$ and the most extended incubation period ( $300 \mathrm{~min}$ ). The generation of degradation byproducts was observed in the samples submitted to oxidizing media ( 12 by-products) and in the samples submitted to the enzymatic medium (a by-product). Thus, it is concluded that enzymatic media are more effective than oxidizing means in the removal of progesterone and that the generation of byproducts from progesterone occurs along with the exposure to both media.

Keywords: Endocrine Disrupting Compounds; Hormones; Byproducts.

\section{Transformações químicas e enzimáticas da progesterona em processos de simulação de tratamento de água em escala laboratorial}

\begin{abstract}
A remoção de compostos desreguladores endócrinos (EDCs) presentes em águas e efluentes foi proposta tanto por métodos de tratamento físico, químico e biológico quanto pelo uso de enzimas produzidas por seres vivos. Embora alguns métodos se mostrem eficientes, é sabido que a transformação de esteróides pode gerar subprodutos com capacidade disruptiva semelhante ou aumentada sobre os compostos originais. Este estudo teve como objetivo avaliar a remoção da molécula de progesterona em meios oxidantes e enzimáticos e. para verificar a formação de subprodutos. As amostras foram avaliadas em diferentes condições quando submetidas a meios oxidantes $(\mathrm{pH}$, tempo, temperatura, salinidade) e meio enzimático $(\mathrm{pH}$, tempo, concentração enzimática). A partir das análises, verificou-se que as amostras submetidas ao meio oxidante apresentaram menor remoção média (18,7\%) do que as amostras submetidas à lacase enzimática $(36,7 \%)$. Entre as amostras submetidas ao meio oxidante, observou-se influência positiva do peróxido de hidrogênio na remoção média de progesterona (20,8\%). Enquanto para as amostras submetidas ao meio enzimático favorecido a remoção da progesterona (43,9\%) ocorreu na solução tampão pH 5 e no período de incubação mais prolongado (300 $\mathrm{min}$ ). A geração de subprodutos de degradação foi observada nas amostras submetidas ao meio oxidante (12 subprodutos) e nas amostras submetidas ao meio enzimático (subproduto). Assim, conclui-se que os meios enzimáticos são mais eficazes que os meios oxidantes na remoção da progesterona e que a geração de subprodutos da progesterona ocorre juntamente com a exposição a ambos os meios.
\end{abstract}

Palavras-chave: Compostos desreguladores endócrinos; Hormônios; Subprodutos.

Topic: Desenvolvimento, Sustentabilidade e Meio Ambiente

Reviewed anonymously in the process of blind peer.

Thiago Caique Alves

Universidade de Blumenau, Brasil

http://lattes.cnpq.br/1327513923808130

http://orcid.org/0000-0002-5651-6562

tcalves@furb.br

Karina Reinicke Dalke

Fundação Universidade Regional de Blumenau, Brasil

http://lattes.cnpq.br/8467090669693511

http://orcid.org/0000-0002-4364-3159

karina_tbo@hotmail.com

Adilson Pinheiro (it

Fundação Universidade Regional de Blumenau, Brasil

http://lattes.cnpq.br/7655568160453478

http://orcid.org/0000-0001-8546-0046

pinheiro@furb.br

6

DOI: 10.6008/CBPC2179-6858.2020.002.0023
Received: 05/02/2020

Approved: 04/03/2020
Referencing this:

ALVES, T. C.; DALKE, K. R.; PINHEIRO, A.. Chemical and enzymatic transformations of progesterone in simulation water treatment processes at laboratory scale. Revista Ibero Americana de Ciências Ambientais, v.11, n.2, p.213-227, 2020. DOI:

http://doi.org/10.6008/CBPC2179-6858.2020.002.0023 


\section{INTRODUCTION}

The contamination of environmental matrices by the presence of organic micropollutants from anthropic sources has become one of the most urgent issues to be solved during the last decades (GARCIAMORALES et al., 2015). Some of these micropollutants are called endocrine disrupting compounds (EDCs) and have attracted attention. When present in the environment even at deficient concentrations ( $\mu \mathrm{g} \mathrm{L}^{-1}$ to $\mathrm{ng} \mathrm{L}^{-1}$ ), they may interfere with the functioning of the endocrine system of humans, as well as other animals (FANG et al., 2016), blocking or mimicking the effect of hormones, affecting their synthesis or metabolism and altering the levels of hormone receptors (BARREIROS et al., 2016).

Among the endocrine disrupting compounds with the most significant capacity to negatively influence the endocrine system are natural and synthetic steroid hormones, such as estrogen (estrone, estradiol, estriol, 17- $\alpha$-ethynylestradiol), androgenic (testosterone) and progestogenic (progesterone, levonorgestrel). These compounds are commonly excreted in the urine and feces of humans and animals, and their insertion into the environment is mainly attributed to the discharge of untreated sewage or ineffective treatment (CHANG et al., 2011; LEUSCH et al., 2017), which contributes to its presence in surface water and groundwater (FANG et al., 2016; FAYAD et al., 2013; GOTARDO et al., 2014; LEECH et al., 2009; STRECK, 2009).

The investigation of methods capable of reducing or inactivating such chemical compounds in water and effluent treatment plants is increasing. With technical proposals aimed at both physical/chemical treatment and the use of advanced oxidation processes (AOPs), ultralight exposure violet (UV), ozonation and adsorption; conventional biological treatment and making use of enzymes produced by microorganisms such as fungi, algae, and bacteria (ARCHER et al., 2017; VILELA et al., 2018).

Among the enzymes that stand out in the removal of EDC are the laccases produced by fungi. Its potential is related to its low specificity, being able to oxidize, in the presence and absence of mediators, a large variety of xenobiotic compounds, some of these recalcitrant, with high redox potential, including chlorinated and non-chlorinated phenolic compounds, pesticides and polycyclic aromatic compounds (GASSER et al., 2014; RAO et al., 2014).

Although some methods of removing EDCs at effluent treatment plants demonstrate, depending on the method and the compound, removal efficiency of 80 to 100\% (CHANG et al., 2011), it is known that the transformation of steroids can generate byproducts with similar or increased estrogenicity concerning the generating compounds, offering environmental and public health risk. Thus, the disappearance of the parent compound does not necessarily imply that the treatment was effective (ALVES et al., 2017; GARCIA-MORALES et al., 2015).

In contrast to this approach of only evaluating the presence/absence of a particular compound, at the end of the use of a given technique, recent studies seek to identify how the mechanisms used in water and effluent treatment interact with EDCs by carefully analyzing which conditions can transform each one of the compounds and clarify the generation of by-products (CHEN et al., 2017; HE et al., 2016; IFELEBUEGU et 
al., 2016; NOUTSOPOULOS et al., 2015; OJOGHORO et al., 2017; ZDARTA et al., 2018). Thus, considering the exposure of the progesterone molecule to different reaction media, as oxidizing and enzymatic means, it is sought to understand how they act and, whether or not they favor the transformation of the progesterone molecule and the generation of by-products.

\section{MATERIALS AND METHODS}

\section{Materials}

The standard Progesterone used was purchased from Sigma-Aldrich, (> 97\%), and the enzyme Laccase Nova Nordisk BioChem (NS29033). The enzyme was in an aqueous solution, which was kept under refrigeration. All other materials were all purchased above $99 \%$ and proven by J. T. Baker. No other material was tested after further purification. Table 1 shows the physicochemical characteristics of Progesterone.

Table 1: Physical-chemical characteristics of the hormone progesterone.

\begin{tabular}{|c|c|c|c|c|c|c|}
\hline Fórmula Empírica & $\mathrm{MM}\left(\mathrm{g} \mathrm{mol}^{-1}\right)$ & Ws (mg L-1 a $\left.25^{\circ} \mathrm{C}\right)$ & Log Kd & pKa & $t_{1 / 2}(h)$ & Número CAS \\
\hline $\mathrm{C}_{21} \mathrm{H}_{30} \mathrm{O}_{2}$ & 314,46 & 8,81 & 4,63 & 18,47 & 55,84 & $57-83-0$ \\
\hline
\end{tabular}

Source: Peng et al. (2014), MarvinSketch (2017), Sigma-Aldrich (2017).

MM: Molecular Weight; Ws: Solubility in water; Kd: Distribution constant; pKa: log de Ka (Acidity Constant); $t_{1 / 2}:$ Halflife time; Number CAS: Register number at Chemical Abstracts Service

\section{Methods}

\section{Chemical Transformation of Progesterone}

Physical-chemical transformation tests consisted of the evaluation of the influence of different physical and chemical agents on the transformation of progesterone. To determine the experimental design, the Response Surface Methodology (MSR) was applied, in which the influence of 5 factors with two levels each was evaluated, namely: $\mathrm{pH}$ of the buffer solution (5 and 9); presence of reducing agent, Sodium Hypochlorite $(\mathrm{NaClO})$ or oxidizing agent, Hydrogen Peroxide $\left(\mathrm{H}_{2} \mathrm{O}_{2}\right)$; salinity $\left(0\right.$ and $\left.10 \mathrm{~g} \mathrm{~L}^{-1}\right)$; temperature (20 and $40{ }^{\circ} \mathrm{C}$ ) and incubation time (30 and $120 \mathrm{~min}$ ). Also, the central point of each factor was determined in order to estimate the experimental error and also to test if there are significant non-linear effects.

For the batch tests (in duplicate) were used Erlenmeyer of $200 \mathrm{~mL}$, with the total volume of $50 \mathrm{~mL} ; 5$ mg solid progesterone, $38 \mathrm{ml}$ acetate buffer (CH3COONa) $2 \mathrm{~mol} \mathrm{~L}^{-1}(\mathrm{pH} \mathrm{5.0)}$ or boric acid buffer (H3BO3) / sodium hydroxide ( $\mathrm{NaOH}) 0.1 \mathrm{~mol} \mathrm{~L}^{-1}(\mathrm{pH} 9.0)$ and $12 \mathrm{ml}$ of sodium hypochlorite (NaClO-) or; $46 \mathrm{~mL}$ acetate buffer ( $\mathrm{CH} 3 \mathrm{COONa}) 2 \mathrm{~mol} \mathrm{~L}^{-1}(\mathrm{pH} 5.0)$ or boric acid buffer (H 3 BO 3) / sodium hydroxide (NaOH) $0.1 \mathrm{~mol} \mathrm{~L}^{-1}$ ( $\mathrm{pH} 9.0)$ and $4 \mathrm{~mL}$ of hydrogen peroxide ( $\mathrm{H} 2 \mathrm{O} 2)$. When the presence of the salinity factor was evaluated, 0.5 g sodium chloride $(\mathrm{NaCl})$ was added to each Erlenmeyer, corresponding to $10 \mathrm{~g} \mathrm{~L}^{-1}$.

The incubation of the samples was performed in the incubator chamber at the desired temperature (20 and $40^{\circ} \mathrm{C}$ ), under the agitation of $150 \mathrm{rpm}$. For the center point samples, $5 \mathrm{mg}$ of solid progesterone, 50 $\mathrm{ml}$ of $0.1 \mathrm{~mol} \mathrm{~L}^{-1}$ phosphate buffer solution ( $\mathrm{pH} \mathrm{7.0)}$ and $0.25 \mathrm{~g}$ of sodium chloride ( $\mathrm{NaCl}$ ) were added to each Erlenmeyer flask. It was incubated at $30{ }^{\circ} \mathrm{C}$ for $75 \mathrm{~min}$. For each incubation temperature control samples were prepared, whose Erlenmeyers contained only $50 \mathrm{~mL}$ of distilled water and $5 \mathrm{mg}$ of solid progesterone. 
After incubation, samples were transferred and concentrated in solid-phase extraction (SPE) cartridges, which were preconditioned three times with $5 \mathrm{~mL}$ of methanol and three times with $5 \mathrm{~mL}$ of water. All compounds of interest were extracted from the SPE with $5 \mathrm{~mL}$ of P.A Methanol and collected in a $10 \mathrm{~mL}$ test tube. The extracted volume was transferred to $1.5 \mathrm{ml}$ amber flasks, which were kept at a temperature of less than $0^{\circ} \mathrm{C}$ until the chromatographic analyses were carried out.

\section{Enzymatic Transformations}

The enzymatic activity of laccase was determined according to the methodology of Wolfendon and Wilson (1982), where the oxidation of 2,2-azinobis (3-ethylbenzthiazoline) -6-sulphonate (ABTS) was conducted in a reaction mixture of $2.1 \mathrm{~mL}$, containing $1 \mathrm{~mL}$ of $0.1 \mathrm{~mol} \mathrm{~L}^{-1}$ phosphate buffer $(\mathrm{pH} 6.5), 1 \mathrm{~mL}$ of ABTS $1 \mathrm{mmol} \mathrm{L}-1$ and $0.1 \mathrm{~mL}$ of enzyme solution at a temperature of $35^{\circ} \mathrm{C}$.

The oxidation of the substrate was carried out under greenhouse conditions at $35^{\circ} \mathrm{C}$ and determined after $10 \mathrm{~min}$ of UV / visible spectrophotometer reaction at $420 \mathrm{~nm}\left(\varepsilon\right.$ at $\left.420 \mathrm{~nm}: 36000 \mathrm{~mol} \mathrm{~L}^{-1} \mathrm{~cm}^{-1}\right)$. The control samples were characterized by the absence of an enzymatic solution, which was replaced by $0.1 \mathrm{~mL}$ of distilled water.

One unit of laccase activity (one-unit enzyme) was defined as the variation in absorbance of the sample at $420 \mathrm{~nm}$ in $10 \mathrm{~min}$. The change in absorbance at $10 \mathrm{~min}$ was equivalent to $\mu \mathrm{mol} \mathrm{L}^{-1}$ of oxidized ABTS in $10 \mathrm{~min}$. This result was then converted to $\mathrm{u} \mathrm{mol} \mathrm{L}^{-1}$ of oxidized ABTS per min to calculate the enzymatic activity (IU). One unit of the enzyme (U.min ${ }^{-1}$ ) was defined as the amount of enzyme capable of oxidizing 1 $\mu \mathrm{mol}$ of substrate per minute. For the enzymatic calculation, we used Equation 1 (SCMITT et al., 2009):

$$
\frac{U}{m L}=\frac{\Delta A b s \cdot 60 . V_{\text {total }} 100000}{\epsilon_{A B T S} \cdot V_{\text {sample. }}}
$$

Where: $\triangle A$ Abs $=$ Increased absorbance at wavelength $420 \mathrm{~nm} ; \varepsilon=$ Absorbance coefficient for ABTS $(\varepsilon 420)(=36,000 \mathrm{~L}$ $\left.\mathrm{mol}^{-1} \mathrm{~cm}^{-1}\right) ;$ Vtotal $=$ total volume $(\mathrm{mL})$ of the mixing reaction in the cuvette; Vsample = volume $(\mathrm{mL})$ of the enzymatic solution used in the mixing reaction; $\mathrm{t}=$ reaction time $(\mathrm{min})$

The experimental design of Enzyme Transformation Assays was also performed through Response Surface Methodology (MSR), where the influence of two concentrations of laccase was evaluated in two pH values and two incubation periods, aiming at determining which factors which favor the degradation of progesterone.

In order to perform the experiment, three factors were used: enzymatic concentration ( 250 and 750 U), buffer $\mathrm{pH}$ (5 and 6.5), and incubation time (60 and $300 \mathrm{~min}$ ). The tests were performed in batch and duplicate. Central spot samples with $500 \mathrm{U}$ enzymatic concentration and pH 5.75 buffer were also prepared. For these samples, the volume of $1.61 \mathrm{~mL}$ of the enzyme, $47.39 \mathrm{~mL}$ of $0.1 \mathrm{~mol} \mathrm{~L}^{-1}$ phosphate buffer solution, and $5 \mathrm{mg}$ of progesterone solubilized in $1 \mathrm{~mL}$ of acetonitrile was used.

Samples were placed together in the incubator chamber at a temperature of $35 \varnothing \mathrm{C}$ and shaking at $150 \mathrm{rpm}$ and, as the incubation time was complete $(60,180$, and $300 \mathrm{~min})$ were withdrawn for extraction. Control samples consisted of flasks containing only $50 \mathrm{~mL}$ of distilled water and $5 \mathrm{mg}$ of progesterone solubilized in $1 \mathrm{~mL}$ of acetonitrile. 
The samples were extracted as described for the physical-chemical tests. Each sample was then diluted by transferring $2 \mathrm{~mL}$ of the volume to a $250 \mathrm{~mL}$ volumetric flask and filling with distilled water. The diluted samples were transferred to two amber flasks of $1.5 \mathrm{ml}$ each and kept in a freezer at a temperature below $0{ }^{\circ} \mathrm{C}$ until the chromatographic analyses were carried out.

A total of $200 \mathrm{~mL}$ Erlenmeyer was used, corresponding to $5 \mathrm{mg}$ of progesterone solubilized in $1 \mathrm{~mL}$ of acetonitrile, $48.19 \mathrm{~mL}$ of $0.1 \mathrm{~mol} \mathrm{~L}^{-1}$ phosphate buffer solution ( $\mathrm{pH} 5$ or 6,5$)$, supplemented with $0.81 \mathrm{ml}$ of enzyme to the enzymatic concentration of $250 \mathrm{U}$ or; $46.58 \mathrm{ml}$ of $0.1 \mathrm{~mol} \mathrm{~L}^{-1}$ phosphate buffer solution (pH 5 or 6.5 ) and complete with $2.42 \mathrm{ml}$ of the enzyme for the enzymatic concentration of $750 \mathrm{U}$.

\section{Progesterone determination}

The determination of progesterone concentrations was performed according to Almeida et al. (2006), using a Dionex Ultimate 3000 HPLC with DAD detection. The mobile phase consisted of an aqueous solution of $10 \%(\mathrm{v} / \mathrm{v})$ acetonitrile and acetonitrile PA, gradient from 0 to $100 \%$ acetonitrile over $60 \mathrm{~min}$, and a flow of $1 \mathrm{ml} \mathrm{min}^{-1}$. The column used was C18 (150 mm x $4 \mathrm{~mm}$, five $\left.\mu \mathrm{m}\right)$, and the detector used the $200 \mathrm{~nm}$ range for progesterone. The column temperature was $25^{\circ} \mathrm{C}$, and the injection volume was $200 \mu \mathrm{L}$. As the samples were concentrated in the SPE, the final concentration of progesterone was determined by calculations.

For the degradation by-products analysis, a liquid chromatography system (Agilent model LC 1260 Infinity) was used, with a 600 bar quaternary pump, automatic sampler model G1329B, equipped with an Eclipse Plus $\mathrm{C} 18$ column $50 \mathrm{~mm}$ long by $2.1 \mathrm{~mm}$ diameter and $1.8 \mu \mathrm{m}$ porosity and 5 microns Eclipse Plus C18 2.1x $12.5 \mathrm{~mm}$ guard column coupled to the mass spectrometer (model 6420 Triple Quad LC / MS, Agilent), with electron ionization mode -spray (ESI). Progesterone molecular ions ( $\mathrm{m} / \mathrm{z} 315,123$, and 109) were monitored, and analysis was performed in Full-Scan mode for the identification of degradation byproducts.

\section{Treatment and data analysis}

Statistical analyses were performed using Statistica ${ }^{\circledR} 7.0$ software, in which descriptive statistical analyses were performed, such as standard deviation, mean, statistical significance, confidence interval. The data obtained had their means compared by Analysis of Variance (ANOVA) according to a single criterion, with a level of significance $(\alpha)$ of 0.05 . The Tukey test was applied when verified by ANOVA that the means of the treatments presented a significant difference in order to investigate which treatments differed from one another.

\section{RESULTS AND DISCUSSION}

\section{Progesterone Analyzes}

Analytical results, as well as linearity studies and limiting detection and quantification calculations, are presented in the supplemental material. The calibration curve had a linear adjustment according to the 
presented model. In this way, the methodology was validated from the linearity studies, which were conclusive regarding the results and limits. Ultraviolet spectra obtained from the progesterone standard at $1.5 \mathrm{mg} \mathrm{L}-1$ were used as standard. There was a mean correspondence of all ultraviolet spectra for the quantized signals of $97.46 \%$. All quantified progesterone chromatographic peaks did not show a change in retention time greater than 0.3 minutes. In this way, and associated with the fine adjustments of linearity, we could trust the results presented in the study.

Table 1: Calibration curve data and Limites of detection and quantification (LOD and LOQ, respectively).

\begin{tabular}{|l|l|l|l|l|}
\hline Compound & Retention Time $(\mathbf{m i n})$ & $\mathbf{R}^{\mathbf{2}}$ & LOD $\left(\mathbf{m g ~ L}^{-\mathbf{1}}\right)$ & $\mathbf{L O Q}\left(\mathbf{m g ~ L}^{-1}\right)$ \\
\hline Progesterone & 10,83 & 0,9990 & 0,14 & 0,43 \\
\hline
\end{tabular}

\section{Physico-chemical degradation of Progesterone}

The final concentration of progesterone in the samples submitted to the physicochemical treatments varied from 55.69 to $95.67 \mu \mathrm{L} \mathrm{L}^{-1}$, and the percentage of removal observed ranged from 0 to $41.3 \%$. The final mean progesterone concentration of all samples submitted to chemical treatments was $77.05 \mu \mathrm{g} \mathrm{L}^{-1}$, and the mean observed removal was $18.6 \%$.

The lowest final concentrations of progesterone $\left(55.69,59.40\right.$, and $\left.67.98 \mu \mathrm{g} \mathrm{L}^{-1}\right)$ and consequently the highest percentages of removal after treatments (41.3, 37.3 and $28.3 \%)$ were observed in samples subjected to the action of the hydrogen peroxide agent $\left(\mathrm{H}_{2} \mathrm{O}_{2}\right)$.

Is was used the median concentrations of all the samples and observed against the effect of reducing agents hydrogen peroxide $\left(\mathrm{H}_{2} \mathrm{O}_{2}\right)$ and sodium hypochlorite $(\mathrm{NaClO})$ in the removal of progesterone. It was observed that the lowest final concentration occurred in samples submitted to the action of hydrogen peroxide $\left(75.07 \mu \mathrm{g} \mathrm{L}^{-1}\right)$, corresponding to the mean removal of $20.8 \%$.

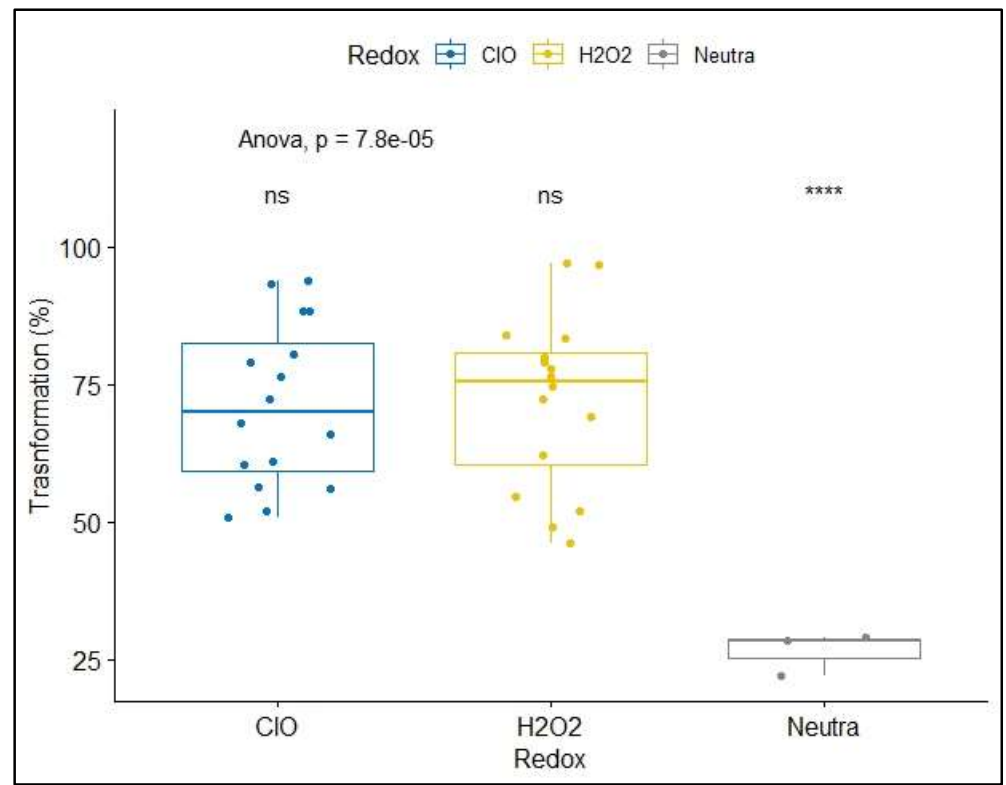

Figure 1: Final median progesterone concentration in the samples subjected to the action of Hydrogen Peroxide $\left(\mathrm{H}_{2} \mathrm{O}_{2}\right)$, Sodium Hypochlorite $(\mathrm{NaClO})$, and no reducing agent (central point).

The evaluation of the isolated use of hydrogen peroxide $\left(\mathrm{H}_{2} \mathrm{O}_{2}\right)$ in the removal of EDCs in effluents is not a common practice since other techniques are usually used together to favor the formation of hydroxyl 
radicals, such as ultraviolet (UV), iron ion (II) $\left(\mathrm{Fe}^{2+}\right)$ or ozone $\left(\mathrm{O}_{3}\right)$. Thus, the percentages of removal observed were lower than those observed in studies that evaluated the removal of other EDCs by combining $\mathrm{H}_{2} \mathrm{O}_{2}$ with different chemical agents. Frontistis et al. (2015) evaluated the removal of EE2 using the UV / $\mathrm{H}_{2} \mathrm{O}_{2}$ combination and observed $100 \%$ removal after 15 min of treatment. Cédat et al. (2016) investigated the degradation of a mixture of estrogen hormones estrone, $\beta$-estradiol, and 17 - $\alpha$-ethynylestradiol) by UV / $\mathrm{H}_{2} \mathrm{O}_{2}$ photolysis in effluent and $80 \%$ of the initial estrogenic compounds could be removed.

When evaluating the action of hydrogen peroxide $\left(\mathrm{H}_{2} \mathrm{O}_{2}\right)$ in the presence of other factors $(\mathrm{pH}$ value, experimental time, temperature and salinity), it was observed that the final concentration of progesterone was lower in samples submitted to $\mathrm{pH} 5\left(55.69\right.$ and $\left.59.40 \mu \mathrm{g} \mathrm{L}^{-1}\right)$, and the presence of salinity at the concentration of $10 \mathrm{~g} \mathrm{~L}^{-1}\left(51.45\right.$ and $\left.56.27 \mu \mathrm{g} \mathrm{L}^{-1}\right)$, indicating that these conditions may favor its action.

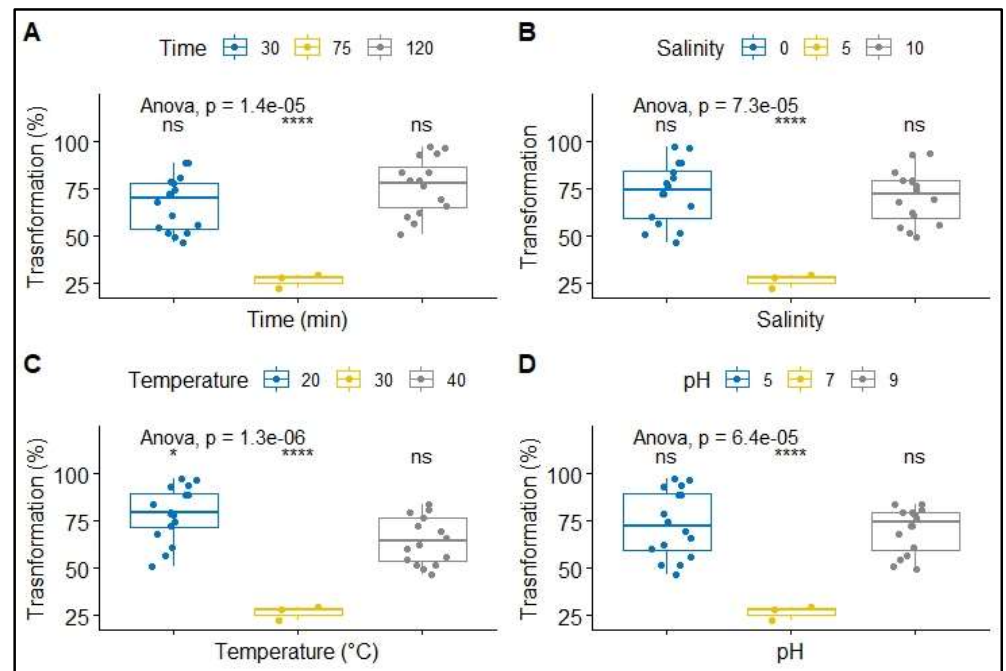

Figure 2: Final medium progesterone concentration of samples subjected experiment time (A), Salinity (B), temperature (C) and salinity (D).

When performing the statistical analysis, it was observed that the agents that most influenced the decrease in concentration were the redox agent and salinity interaction. The presence of salinity and the longer experiment time would be favoring the removal of the progesterone molecule or, possibly, only causing a lower solubility (and in this case availability) of progesterone in the reaction medium. The salinity effect was the only one that present statistical difference when the median data was performed through ANOVA analysis $(p<0,001 ; \alpha=0,05)$.

Yang et al. (2016) found significant negative correlations between the concentrations of salinity and dissolved EDCs. This phenomenon has been widely referred to as salting out and is suggested as the cause of the decrease in the aqueous solubility of most EDCs due to the presence of soluble salts, resulting in the compound being more attracted to the solid phase. This condition may be indicative that of the amount of progesterone removed, a portion may be only insoluble, rather than totally degraded.

The response surface can show us a complete relationship between the chosen variables. In Figure 3 , it can be seen that there is almost a linear relationship between the increase in salinity and the concentration of progesterone in the medium. That is, the less salt, the more degradation of it is favored. 
Something similar, but with less intensity, can be observed in the variable oxidizing agent, where the lower values presented are related to the presence of $\mathrm{H}_{2} \mathrm{O}_{2}$.

Another condition that may have made possible the removal of progesterone was the interaction of the lower $\mathrm{pH}$ and the oxidizing agent hydrogen peroxide $\left(\mathrm{H}_{2} \mathrm{O}_{2}\right)$, with higher percentages of progesterone removal in the samples submitted to $\mathrm{pH} 5$.

Zhang et al. (2014) evaluated the effects of $\mathrm{H}_{2} \mathrm{O}_{2}$ dosage and $\mathrm{pH}$ on the removal of six endocrine

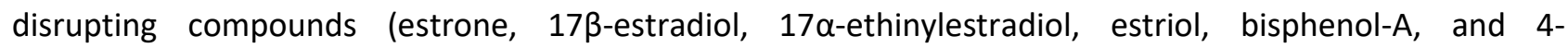
nonylphenols) from TSE sludge with treatment by activated sludge and observed that the low $\mathrm{pH}$ value is favorable for the removal of EDCs in the different dosages of $\mathrm{H} 2 \mathrm{O} 2$ tested $\left(0.05-2 \mathrm{~mol} \mathrm{~L}^{-1}\right)$, being that in the dosage with $\mathrm{pH}$ three and $\mathrm{H}_{2} \mathrm{O}_{2}$ of $2 \mathrm{~mol} \mathrm{~L}^{-1}$, the highest removal efficiencies of Estrone (E1), 17- $\alpha$ ethinylestradiol (EE2), Estriol (E3), Bisphenol-A (BPA) and 4-nonylphenols (NP) were observed 73, 58, 58, 54 and $46 \%$, respectively.

What may explain the favoring of the action of $\mathrm{H}_{2} \mathrm{O}_{2}$ in the removal of the EDCs at lower $\mathrm{pH}$ is that, in contrast, the increase in $\mathrm{pH}$ can cause the formation of an inactive hydroperoxide anion $\left(\mathrm{HO}_{2}{ }^{-}\right)$due to the dissociation of $\mathrm{H}_{2} \mathrm{O}_{2}$. This $\mathrm{HO}_{2}^{-}$anion can act as an efficient eliminator of hydroxyl radicals, which leads to the inhibition of degradation (BOUASLA et al., 2010). Thus, $\mathrm{H}_{2} \mathrm{O}_{2}$ becomes unstable and decomposed to molecular oxygen at alkaline pH, losing its oxidation capacity (ZHANG et al., 2014).

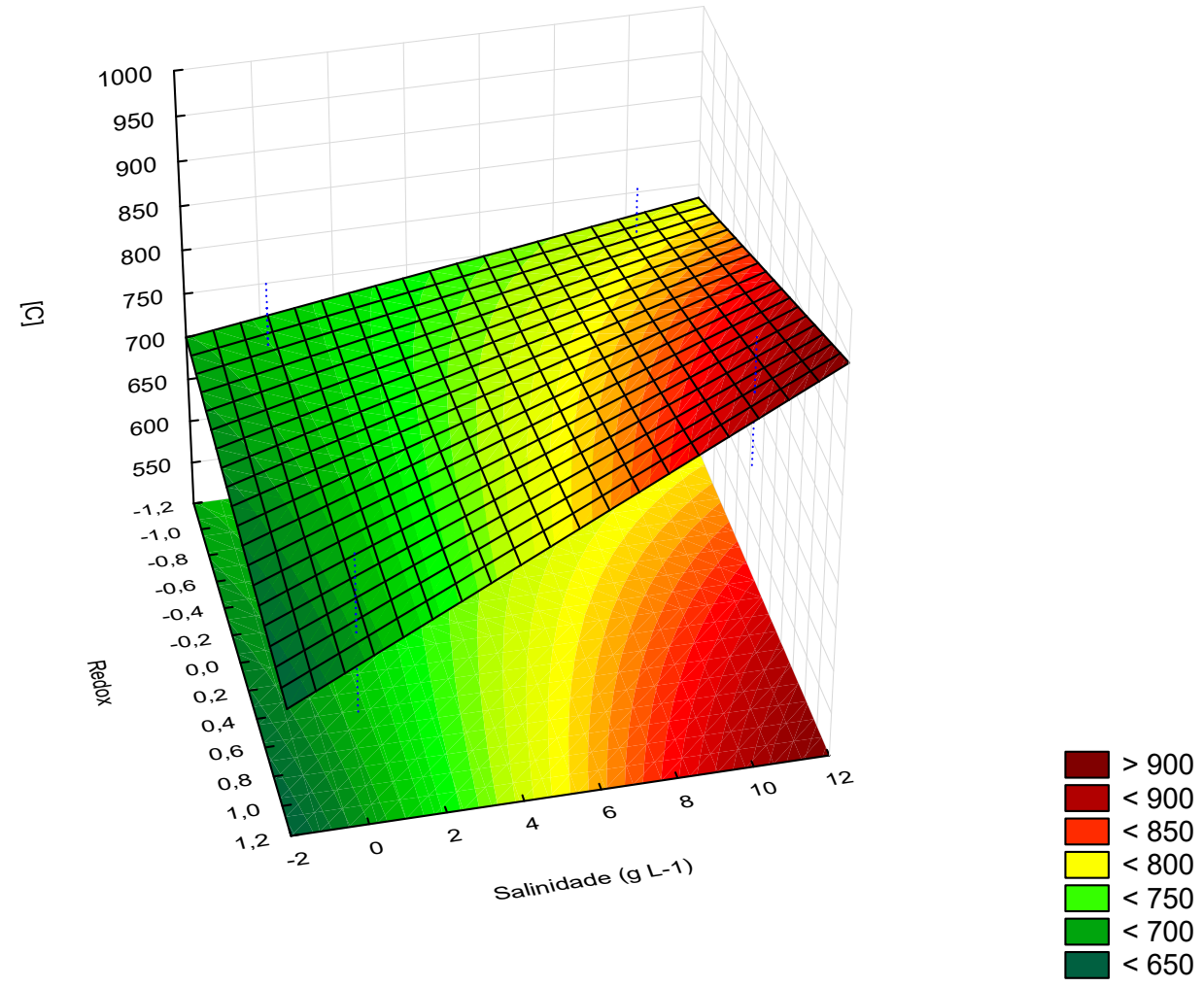

Figure 3: Response Surface for the relation between observed concentration, redox agent, and salinity. Redox value: $\mathrm{H}_{2} \mathrm{O}_{2}(-1)$; Neutral (0) and $\mathrm{ClO}^{-}(+1)$. 
Hypochlorite ( $\left.\mathrm{NaClO}^{-}\right)$samples showed concentrations at or above the central point $\left(79.09 \mu \mathrm{g} \mathrm{L}^{-1}\right)$, which samples did not have a reducing agent. In the same way, the different conditions of $\mathrm{pH}$, time of the experiment, temperature, and salinity did not stand out favoring the removal of progesterone by $\mathrm{NaClO}^{-}$.

The variation in the $\mathrm{pH}$ value in the samples submitted to the action of sodium hypochlorite did not show any significant influence on the removal of progesterone. This condition is different from that observed in studies that studied the degradation of estradiol (E2) by hypochlorite (HE et al., 2016; LI et al., 2017), where increasing the $\mathrm{pH}$ value favored degradation.

Likewise, the two temperatures applied did not show a significant difference in progesterone removal performance, which differed from Ifelebuegu et al. (2016) who observed an increase in the rate of progesterone degradation with increasing temperature, a fact that attributed the improvement of the generation of hydroxyl radicals at high temperatures, increasing the rate of degradation and thus accelerating the degradation of the molecule.

\section{Enzymatic Effect}

The result of the enzymatic activity assay of laccase was $309.89 \mathrm{U} \mathrm{mL}^{-1}$ (standard deviation of 120.65 and coefficient of variation of 38.9\%). From the result of the enzymatic activity, it was possible to determine the volume of the enzymatic solution used for each of the enzymatic activity tested.

The concentration of progesterone in samples submitted to laccase enzyme activity ranged from 72.35 to $107.55 \mu \mathrm{g} \mathrm{L} \mathrm{L}^{-1}$. Removal values ranged from 44.8 to $17.9 \%$ and were below what Spina et al. (2015) observed when analyzing the application of fungal laccases in the removal of steroid hormones Estrone, 17$\alpha$-ethynylestradiol and $17-\beta$-estradiol, which was $98.8 ; 100$ and $100 \%$, respectively.

Table 2: ANOVA Values for the enzymatic interactions with the removal of Progesterone.

\begin{tabular}{|l|l|l|l|l|l|}
\hline Factor & SS & df & MS & F & p \\
\hline $\mathrm{pH} \mathrm{(Q)}$ & 153833,0 & 1 & 153833,0 & 828,2142 & 0,000009 \\
\hline Tempo (h)(L) & 161,9 & 1 & 161,9 & 0,8715 & 0,403395 \\
\hline [C] Enzyme(L) & 7,7 & 1 & 7,7 & 0,0416 & 0,848366 \\
\hline Error & 743,0 & 4 & 185,7 & & \\
\hline Total SS & 154752,4 & 8 & & & \\
\hline
\end{tabular}

Statistical analysis indicated that progesterone removal was favored in the samples, which were carried out in buffer solution at $\mathrm{pH}$ five and for a more extended period of 300 minutes (44 and $43.0 \%$ ),

A similar result was obtained in the use of laccase enzyme for the removal of Bisphenol A (BPA). Zdarta et al. (2018) tested the removal of BPA in the pH range from 4 to 8 and recorded that the biodegradation efficiency for BPA increased to the maximum at $\mathrm{pH} 5$ and decreased as the $\mathrm{pH}$ became higher. The authors related directly to the catalytic properties of laccase, which would have properties of higher catalytic activity and stability at pH 5 (ZDARTA et al., 2018).

Freitas et al. (2017) studied the ability of BPA removal by laccase enzymes of two fungi, concerning $\mathrm{pH}$, both laccases were able to remove $\mathrm{BPA}$ at $\mathrm{pH}$ values ranging from 4 to 7 , and the best results of degradation were obtained at $\mathrm{pH} 5$. 
The comparison of the removal with the enzymatic concentration showed no linear profile, and in identical enzymatic concentrations, significant removal differences were observed. This phenomenon may be due to the limited enzymatic affinity for the substrate, as well as diffusion problems of the substrate, being the concentration and bioavailability of the substrate a crucial and limiting factor (SPINA et al., 2015), availability that may have been affected by the others conditions, such as $\mathrm{pH}$.

The $\mathrm{pH}$ was the only variable that presented significance $(p=0.0001 ; \alpha=0.05)$, which was visualized in figure 4. The response surface presented a model of horse cell, and in it, it was found that the central point of the design was the one that less degraded the progesterone. This can be explained by a possible enzymatic inhibition in this $\mathrm{pH}$ range, making biological degradation impossible.

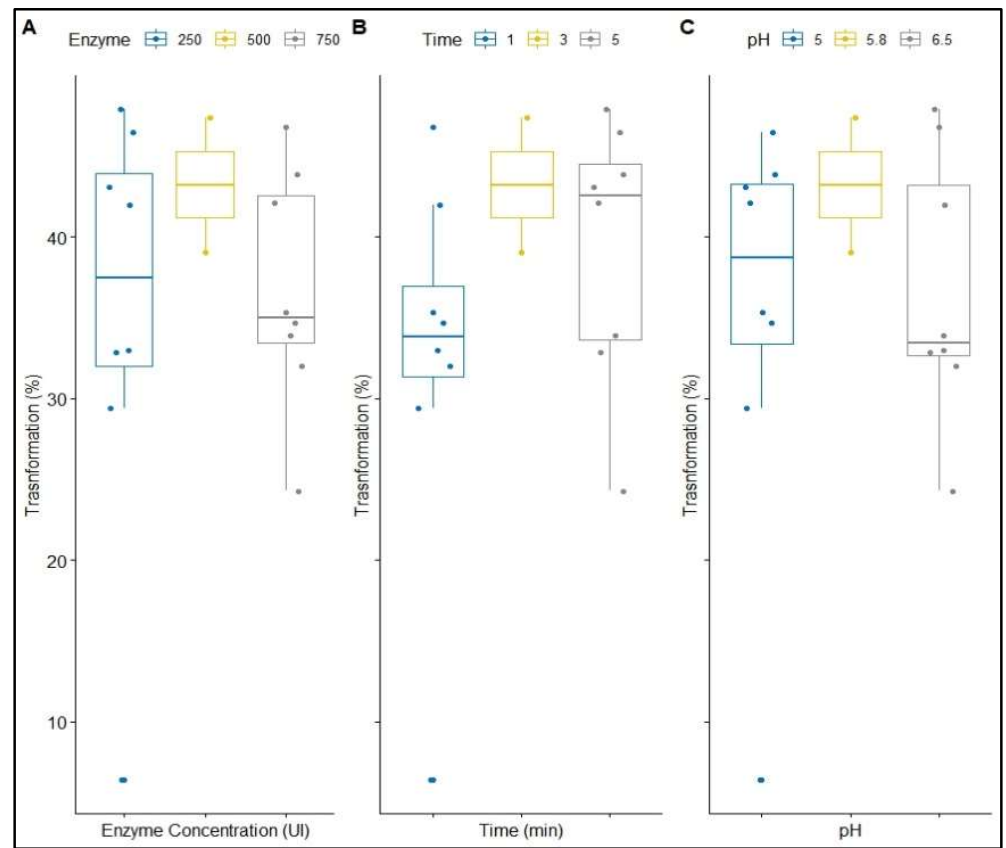

Figure 4: Enzymatic concentration on degradation of progesterone subjected by Enzyme concentration (A), Time (B) and $\mathrm{pH}(\mathrm{C})$.

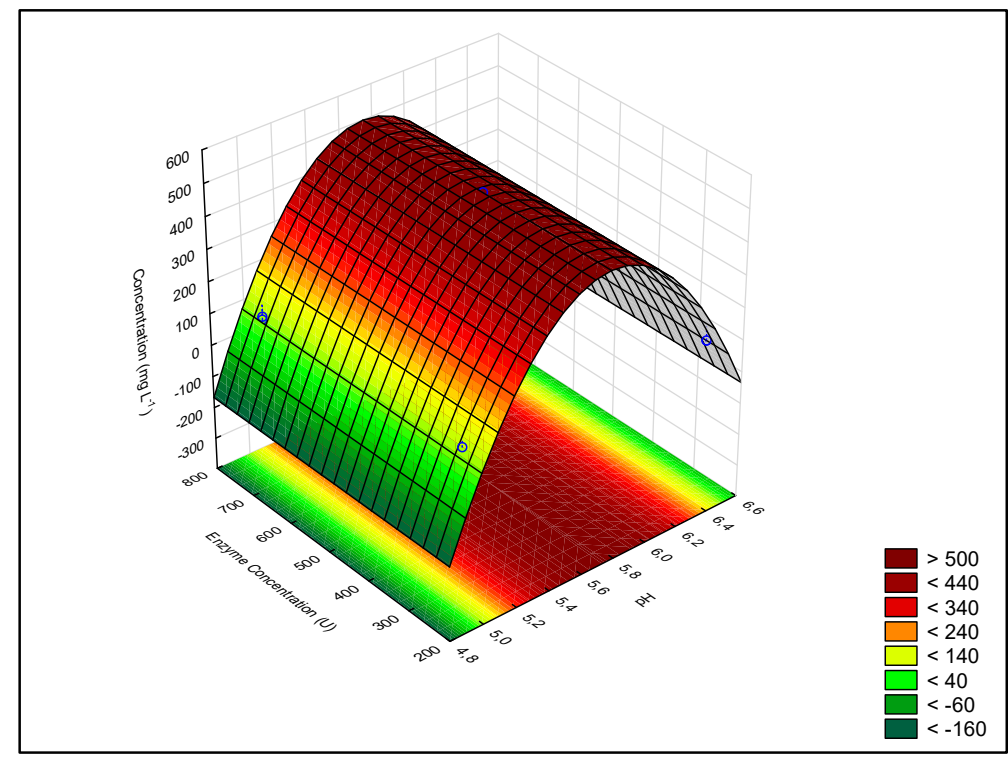

Figure 5: Response Surface for the relation between observed concentration, $\mathrm{pH}$, and Enzymatic concentration os the media. 


\section{Degradation Byproducts}

In the chemical transformation essay, was observed the generation of 12 degradation by-products, having the following mass / charge ratios (m/z): 395, 355, 393, 367, 355, 333, 315, 311, 270, 232, 149, 123. Progesterone must have a molecular weight of $314.47 \mathrm{~g} \mathrm{~mol}^{-1}$. This indicates that in the chemical transformation, some products formed contain some or all of the progesterone molecule and some or all of the oxidant.

The by-product of $\mathrm{m} / \mathrm{z} 395$ was observed only in the samples subjected to the action of $\mathrm{H}_{2} \mathrm{O}_{2}$, whereas the by-product 355 only in the samples submitted to the action of $\mathrm{NaClO}$. The by-products of $\mathrm{m} / \mathrm{z} 393,367$, $333,311,270,232,149$ were observed exclusively under the action of $\mathrm{H}_{2} \mathrm{O}_{2}$, under the condition of $40^{\circ} \mathrm{C}$ temperature and $30 \mathrm{~min}$ of the assay.

Ojoghoro et al. (2017) identified the generation of progesterone degradation byproducts in surface waters through laboratory tests simulating treatment plant tanks. The results showed the formation of six alleged transformation products of the nine monitored target products. The presence of two of the detected products was confirmed by the precise determination of their $\mathrm{m} / \mathrm{z}$ ratios $\left(\mathrm{MM}=312.2\right.$ and $\left.286.2 \mathrm{~g} \mathrm{~mol}^{-1}\right)$, and a third product was detected in the HRMS, but with a lower degree of confidence and without the molecular formula $\left(\mathrm{MM}=316.2 \mathrm{~g} \mathrm{~mol}^{-1}\right)$. The authors attributed the progesterone transformation predominantly to dehydrogenation reactions.

Ifelebuegu et al. (2016) observed changes in progesterone concentration during the Photo-Fenton degradation process. Among the degradation by-products identified, $17 \alpha$-hydroxyl $\left(\mathrm{MM}=331 \mathrm{~g} \mathrm{~mol}^{-1}\right)$, testosterone $\left(\mathrm{MM}=288 \mathrm{~g} \mathrm{~mol}^{-1}\right)$ and dihydrotestosterone $\left(\mathrm{MM}=290 \mathrm{~g} \mathrm{~mol}^{-1}\right)$ were detected after $10 \mathrm{~min}$ of progesterone $\left(\mathrm{Mg}=104 \mathrm{~g} \mathrm{~mol}^{-1}\right)$, acetaldehyde $\left(\mathrm{MM}=44 \mathrm{~g} \mathrm{~mol}^{-1}\right)$, oxalic acid $\left(\mathrm{MM}=90 \mathrm{~g} \mathrm{~mol}^{-1}\right)$, methanoic acid $\left.=46 \mathrm{~g} \mathrm{~mol}^{-1}\right)$. The double bonds in the progesterone molecule between $\mathrm{C} 4$ and $\mathrm{C} 5$, the hydroxyl group in $\mathrm{C} 12$, and the double bond oxygen in $\mathrm{C} 3$ are the probable points of hydroxyl radical attack. The researchers concluded that there was a degradation of progesterone in several stages, involving several common byproducts of transformation that underwent further degradation and rupture of the ring to form simpler organic molecules such as carbon dioxide and water.

No mass/charge $(\mathrm{m} / \mathrm{z})$ ratios of the by-products identified by the progesterone transformation in the present study were equal to the molecular masses of the by-products identified in the two papers cited (IFELEBUEGU et al., 2016; OJOGHORO et al., 2017) only the by-product mass/charge ratio $(\mathrm{m} / \mathrm{z}) 333$ approached the $17 \alpha$-hydroxyl mass $\left(\mathrm{MM}=331 \mathrm{~g} \mathrm{~mol}^{-1}\right)$.

For the determination of which byproducts are generated, additional studies are necessary for equipment such as a high-resolution mass spectrometer. About the enzyme transformation assay samples, only the mass/charge $(\mathrm{m} / \mathrm{z})$ ratios of samples 9 and 18 correspondings to the center point were determined for this work.

When injecting sample 18 , submitted to the enzymatic assay, two distinct signals can be observed at a retention time of 10.1 and 14.9 min. By filtering the chromatograms by the masses, it can be seen that the 
first one is a progesterone ( $\mathrm{m} / \mathrm{z} 315)$, while the second may be some transformation product, but with a mass of 360.5. Through the mass breaks of this second signal, it is possible to observe breaks of $\mathrm{m} / \mathrm{z} 315$ (progesterone), m / z 243; m / z 149 and m / z 123.

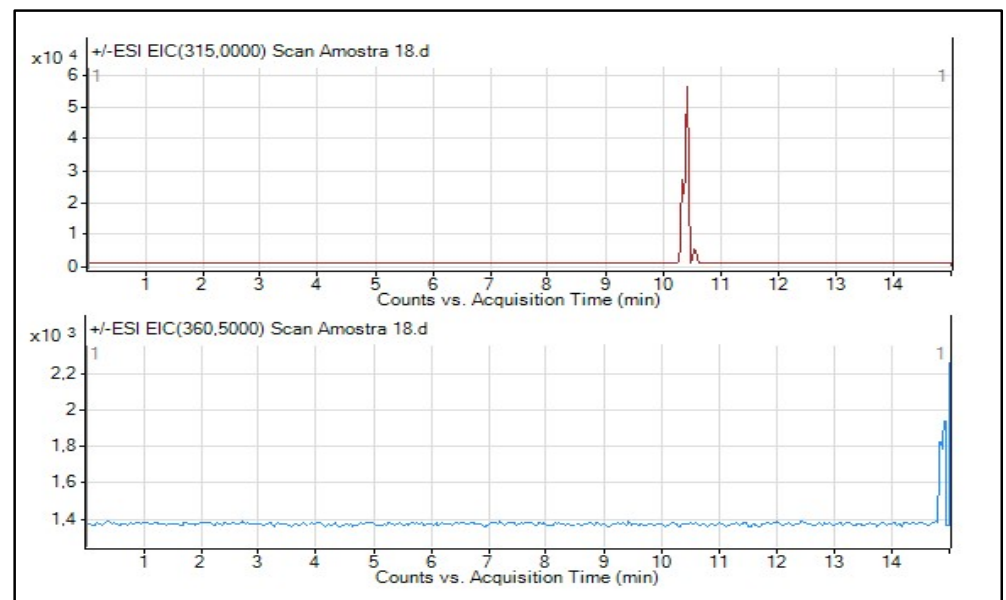

Figure 6: Chromatograms of sample 18, submitted to enzymatic medium, with progesterone signals $(\mathrm{m} / \mathrm{z} 315)$ and some degradation product ( $\mathrm{m} / \mathrm{z} 360.5$ ).

From the mass breaks, one can try to elucidate what the product of transformation would be. As losses of $14.4\left(\mathrm{CH}^{+}\right)$and $31.1\left(=\mathrm{OH}^{+}\right)$are observed, and possibly, depending on the molecular structure, nucleophilic attacks would occur on progesterone instauration. A possible route of degradation of this compound is plausible with the molecular structure of progesterone, as observed in Figure 8. However, further studies are necessary to prove the existence of this molecule and may come from the ionization of the analytical method, or other conformation to be confirmed with subsequent molecular purifications and elucidation.

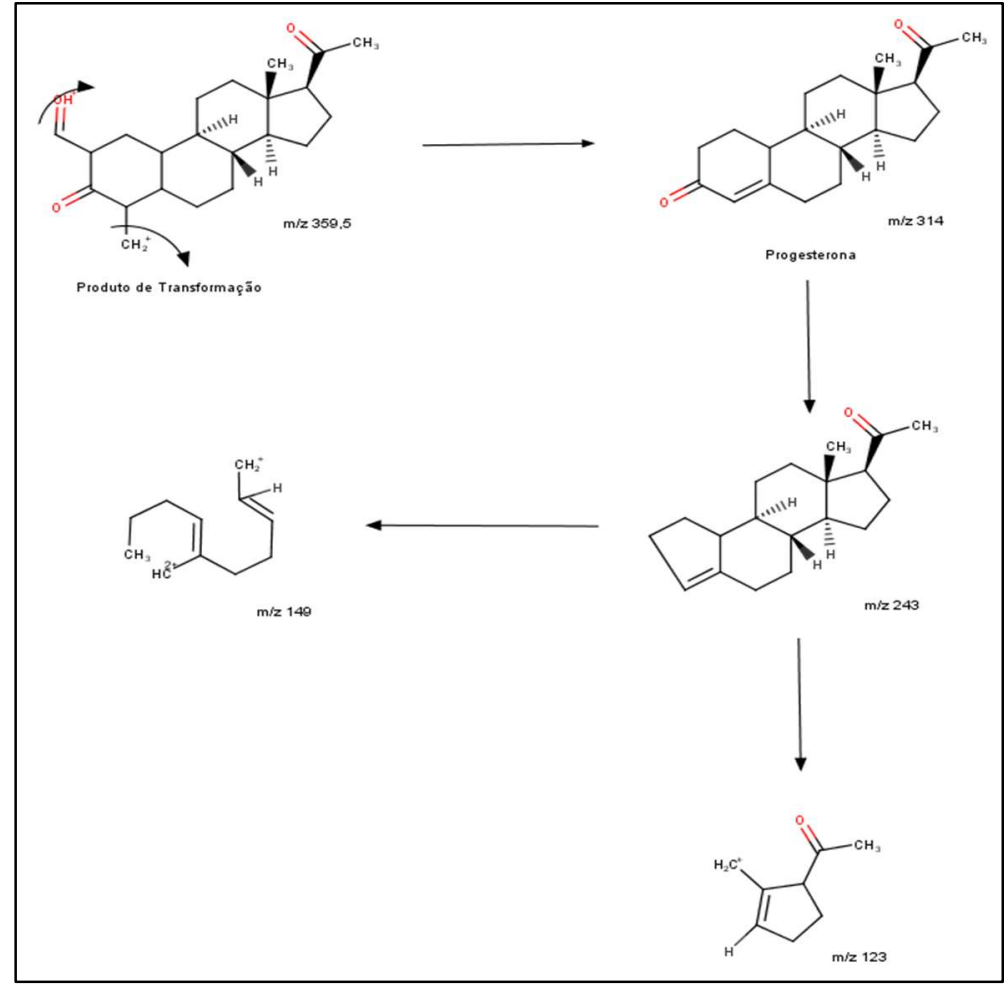

Figure 7: Schematic diagram suggesting possible route of transformation product observed in sample submitted to enzymatic medium. 


\section{CONCLUSIONS}

The results obtained showed that the samples submitted to the oxidizing media had a lower average removal (18.6\%) than those sampled under enzyme laccase (36.7\%); Among the samples submitted to the oxidizing media, the ones submitted to hydrogen peroxide showed a higher average removal (20.8\%). There were 12 by-products of degradation in the samples submitted to the oxidizing media, of which seven byproducts were generated exclusively under the action of $\mathrm{H}_{2} \mathrm{O}_{2}$, in the condition of $40^{\circ} \mathrm{C}$ temperature and 30 min of the test.

In the center point samples of the enzymatic transformation assay, the presence of a by-product of the mass of $360.5 \mathrm{~g} \mathrm{~mol}^{-1}$ was observed. Through the mass breaks of this second signal, it was possible to observe m / z 315 (progesterone) breaks, m / z 243; m / z 149, and m / z 123. Thus, it is concluded that enzymatic media are more effective than oxidizing means in the removal of progesterone and that the generation of byproducts from progesterone occurs throughout the exposure to both oxidizing and enzymatic media.

ACKNOWLEDGMENTS: to CAPES - Brazilian Federal Agency for Support and Evaluation of Graduate Education within the Ministry of Education, Brazil for the financial and PNPD (National Program of Post Doctorate) scholarship supported by the financed with process 88882.317114/2019-01.

\section{REFERENCES}

ALMEIDA, C.; NOGUEIRA, J. M. F.. Determination of steroid sex hormones in water and urine matrices by stir bar sorptive extraction and liquid chromatography with diode array detection. Journal of Pharmaceutical and Biomedical Analysis, v.41, n.4, p.1303-1311, 2006. DOI: http://doi.org/10.1016/i.jpba.2006.02.037

ALVES, T.; GIRARDI, R.; PINHEIRO, A.. Micropoluentes orgânicos: ocorrência, remoção e regulamentação. Revista de Gestão de Água da América Latina, v.14, n.0, p.0-1, 2017.

ARCHER, E.; PETRIE, B.; KASPRZYK-HORDERN, B.; WOLFAARDT, G. M.. The fate of pharmaceuticals and personal care products (PPCPs), endocrine disrupting contaminants (EDCs), metabolites and illicit drugs in a WWTW and environmental waters. Chemosphere, Oxford v.174, p.437-446, 2017. DOI:

http://dx.doi.org/10.1016/j.chemosphere.2017.01.101

BARREIROS, L.; QUEIROZ, J. F.; MAGALHÃES, L. M.; SILVA, A. M. T.; SEGUNDO, M. A.. Analysis of 17- $\beta$-estradiol and $17-\alpha-$ ethinylestradiol in biological and environmental matrices - $A$ review. Microchemical Journal, New York, v.126, p.243-262, 2016. DOI: $\underline{\text { http://dx.doi.org/10.1016/i.microc.2015.12.003 }}$

BOUASLA, C.; SAMAR, M. E. H.; ISMAIL, F.. Degradation of methyl violet $6 \mathrm{~B}$ dye by the Fenton process. Desalination, v.254, n.1-3, p.35-41, 2010. DOI:

http://doi.org/10.1016/j.desal.2009.12.017

CÉDAT, B.; DE BRAUER, C.; MÉTIVIER, H.; DUMONT, N.; CHANG, H.; WAN, Y.; WU, S.; FAN, Z.; HU, J.. Occurrence of androgens and progestogens in wastewater treatment plants and receiving river waters: Comparison to estrogens. Water Research, New York, v.45, n.2, p.732-740, 2011. DOI: http://dx.doi.org/10.1016/j.watres.2010.08.046

CHEN, Y. L.; YU, C. P.; LEE, T. H.; GOH, K. S.; CHU, K. H.; WANG, P. H.; ISMAIL, W.; SHIH, C. J.; CHIANG, Y. R. Biochemical mechanisms and catabolic enzymes involved in bacterial estrogen degradation pathways. Cell Chemical Biology, Cambridge, v.24, n.6, p.712-724.e7, 2017.

FANG, T. Y.; PRAVEENA, S. M.; DEBURBURE, C.; ARIS, A. Z.; ISMAIL, S. N. S.; RASDI, I.. Analytical techniques for steroid estrogens in water samples - A review. Chemosphere, Oxford, v.165, p.358-368, 2016. DOI: http://dx.doi.org/10.1016/j.chemosphere.2016.09.051

FAYAD, P.; ZAMYADI, A.; BROSEUS, R.; PRÉVOST, M.; SAUVÉ, $S$.. Degradation of progestagens by oxidation with potassium permanganate in wastewater effluents. Chemistry Central Journal, London, v.7, n.1, p.84, 2013. 2013.

FREITAS, E. N.; BUBNA, G. A.; BRUGNARI, T.; KATO, C. G.; NOLI, M.; RAUEN, T. G.; MOREIRA, R. F. P. M.; PERALTA, R. A.; BRACHT, A.; SOUZA, C. G. M.; PERALTA, R. M.. Removal of bisphenol $A$ by laccases from Pleurotus ostreatus and Pleurotus pulmonarius and evaluation of ecotoxicity of degradation products. Chemical Engineering Journal, v.330, n.7, p.1361-1369, 2017. DOI: http://dx.doi.org/10.1016/j.cej.2017.08.051

FRONTISTIS, Z.; KOURAMANOS, M.; MORAITIS, S.; 
CHATZISYMEON, E.; HAPESHI, E.; FATTA-KASSINOS, D.; XEKOUKOULOTAKIS, N. P.; MANTZAVINOS, D.. UV and simulated solar photodegradation of $17 \alpha$-ethynylestradiol in secondary-treated wastewater by hydrogen peroxide or iron addition. Catalysis Today, v.252, p.84-92, 2015. DOI: http://dx.doi.org/10.1016/j.cattod.2014.10.012

GARCIA-MORALES, R.; RODRIGUEZ-DELGADO, M.; GOMEZMARISCAL, K.; ORONA-NAVAR, C.; HERNANDEZ-LUNA, C.; TORRES, E.; PARRA, R.; CÁRDENAS-CHÁVEZ, D.; MAHLKNECHT, J.; ORNELAS-SOTO, N.. Biotransformation of Endocrine-Disrupting Compounds in Groundwater: Bisphenol A, Nonylphenol, Ethynylestradiol and Triclosan by a Laccase Cocktail from Pycnoporus sanguineus CS43. Water, Air, and Soil Pollution, Heidelberg, v.226, n.8, p.1-14, 2015.

GASSER, C. A.; AMMANN, E. M.; SHAHGALDIAN, P.; CORVINI, P. F. X.. Advanced enzymatic elimination of phenolic contaminants in wastewater: A nano approach at field scale. Applied Microbiology and Biotechnology, v.98, n.7, p.33053316, 2014

GOTARDO, R.; PINHEIRO, A.; KAUFMANN, V.; ALVES, T. C.; BLAINSKI, E.. Hormones and antibiotics associated with intensive pig production in a river basin. Rega, Porto Alegre, v.11, n.2, p.67-78, 2014.

HE, G.; LI, C.; DONG, F.; ZHANG, T.; CHEN, L.; CIZMAS, L.; SHARMA, V. K.. Chloramines in a pilot-scale water distribution system: Transformation of $17 \beta$-estradiol and formation of disinfection byproducts. Water Research, New York, v.106, p.41-50, 2016. DOI:

http://dx.doi.org/10.1016/j.watres.2016.09.047

IFELEBUEGU, A. O.; UKPEBOR, J.; NZERIBE-NWEDO, B.. Mechanistic evaluation and reaction pathway of UV photoassisted Fenton-like degradation of progesterone in water and wastewater. International Journal of Environmental Science and Technology, v.13, n.12, p.2757-2766, 2016.

LEECH, D. M.; SNYDER, M. T.; WETZEL, R. G.. Natural organic matter and sunlight accelerate the degradation of $17 ß-$ estradiol in water. Science of the Total Environment, v.407, n.6, p.2087-2092, 2009. DOI:

http://dx.doi.org/10.1016/j.scitotenv.2008.11.018

LEUSCH, F. D. L.; NEALE, P. A.; HEBERT, A.; SCHEURER, M.; SCHRIKS, M. C. M.. Analysis of the sensitivity of in vitro bioassays for androgenic, progestagenic, glucocorticoid, thyroid and estrogenic activity: Suitability for drinking and environmental waters. Environment International, Oxford, v.99, p.120-130, 2017. DOI:

http://dx.doi.org/10.1016/j.envint.2016.12.014

LI, C.; DONG, F.; CRITTENDEN, J. C.; LUO, F.; CHEN, X.; ZHAO, T.. Kinetics and mechanism of $17 \mathrm{~B}$-estradiol chlorination in a pilot-scale water distribution systems. Chemosphere, Oxford, v.178, p.73-79, 2017. DOI:

http://dx.doi.org/10.1016/j.chemosphere.2017.03.039

MARVINSKETCH. Versão 5.5. ChemAxon, 2017.

NOUTSOPOULOS, C.; KOUMAKI, E.; MAMAIS, D.; NIKA, M. C.; BLETSOU, A. A.; THOMAIDIS, N. S.. Removal of endocrine disruptors and non-steroidal anti-inflammatory drugs through wastewater chlorination: The effect of $\mathrm{pH}$, total suspended solids and humic acids and identification of degradation by-products. Chemosphere, Oxford, v.119, p.S109-S114, 2015. DOI:

http://dx.doi.org/10.1016/i.chemosphere.2014.04.107

OJOGHORO, J. O.; CHAUDHARY, A. J.; CAMPO, P.; SUMPTER, J. P.; SCRIMSHAW, M. D.. Progesterone potentially degrades to potent androgens in surface waters. Science of the Total Environment, Amsterdam, v.579, p.1876-1884, 2017.DOI: http://dx.doi.org/10.1016/j.scitotenv.2016.11.176

PENG, F. Q.; YING, G. G.; YANG, B.; LIU, S.; LAI, H. J.; LIU, Y. S.; CHEN, Z. F.; ZHOU, G. J.. Biotransformation of progesterone and norgestrel by two freshwater microalgae (Scenedesmus obliquus and Chlorella pyrenoidosa): Transformation kinetics and products identification. Chemosphere, Oxford, v.95, p.581-588, 2014. DOI: http://dx.doi.org/10.1016/j.chemosphere.2013.10.013

RAO, M. A.; SCELZA, R.; ACEVEDO, F.; DIEZ, M. C.; GIANFREDA, L.. Enzymes as useful tools for environmental purposes. Chemosphere, v.107, p.145-162, 2014. DOI: http://dx.doi.org/10.1016/i.chemosphere.2013.12.059

SCHMITT, S.; SOUZA, R.; BETTIN, F.; DILLON, A. J. P.; VALLE, J. A. B.; ANDREAUS, J.. Evaluation of oxidoreductases for the wash-off procedures after textile dyeing. In: INTERNATIONAL CONFERENCE ON TEXTILE AND POLYMER BIOTECHNOLOGY, 6. Anais. Gent, 2009. p.132-138.

SIGMA-ALDRICH. Progesterona: Ficha de Informações de Segurança de Produtos Químicos. 2017.

SPINA, F.; CORDERO, C.; SCHILIRO, T.; SGORBINI, B.; PIGNATA, C.; GILI, G.; BICCHI, C.; VARESE, G. C.. Removal of micropollutants by fungal laccases in model solution and municipal wastewater: evaluation of estrogenic activity and ecotoxicity. Journal of Cleaner Production, Amsterdam, v.100, p.185-194, 2015.

STRECK, G.. Chemical and biological analysis of estrogenic, progestagenic and androgenic steroids in the environment. TrAC - Trends in Analytical Chemistry, v.28, n.6, p.635-652, 2009. DOI: http://dx.doi.org/10.1016/j.trac.2009.03.006

VILELA, C. L. S.; BASSIN, J. P.; PEIXOTO, R. S.. Water contamination by endocrine disruptors: Impacts, microbiological aspects and trends for environmental protection. Environmental Pollution, Oxford, v.235, p.546$559,2018$.

YANG, L.; CHENG, Q.; LIN, L.; WANG, X.; CHEN, B.; LUAN, T.; TAM, N. F. Y.. Partitions and vertical profiles of 9 endocrine disrupting chemicals in an estuarine environment: Effect of tide, particle size and salinity. Environmental Pollution, Oxford, v.211, p.58-66, 2016. DOI: http://dx.doi.org/10.1016/j.envpol.2015.12.034

ZDARTA, J.; ANTECKA, K.; FRANKOWSKI, R.; ZGOLAGRZESKOWIAK, A.; EHRLICH, H.; JESIONOWSKI, T.. The effect of operational parameters on the biodegradation of bisphenols by Trametes versicolor laccase immobilized on Hippospongia communis spongin scaffolds. Science of the Total Environment, Amsterdam, v.615, p.784-795, 2018. DOI: https://doi.org/10.1016/i.scitotenv.2017.09.213

ZHANG, A.; LI, Y.. Removal of phenolic endocrine disrupting compounds from waste activated sludge using $\mathrm{UV}, \mathrm{H}_{2} \mathrm{O}_{2}$, and 
$\mathrm{UV} / \mathrm{H}_{2} \mathrm{O}_{2}$ oxidation processes: Effects of reaction conditions and sludge matrix. Science of the Total Environment,
Amsterdam, v.493, p.307-323, 2014. DOI:

http://dx.doi.org/10.1016/i.scitotenv.2014.05.149

A CBPC - Companhia Brasileira de Produção Científica (CNPJ: 11.221.422/0001-03) detém os direitos materiais desta publicação. Os direitos referem-se à publicação do trabalho em qualquer parte do mundo, incluindo os direitos às renovações, expansões e disseminações da contribuição, bem como outros direitos subsidiários. Todos os trabalhos publicados eletronicamente poderão posteriormente ser publicados em coletâneas impressas sob coordenação da Sustenere Publishing, da Companhia Brasileira de Produção Científica e seus parceiros autorizados. Os (as) autores (as) preservam os direitos autorais, mas não têm permissão para a publicação da contribuição em outro meio, impresso ou digital, em português ou em tradução. 